\title{
KAJIAN ADSORPSI LINEAR ALKYL BENZENE SULPHONATE (LAS) DENGAN BENTONIT-KITOSAN
}

\author{
Miftah Rifai, Irwan Nugraha \\ Universitas Islam Negeri Sunan Kalijaga Yogyakarta \\ Email : miftah.rifai@yahoo.com
}

\begin{abstract}
ABSTRAK
Deterjen pada umumnya tersusun atas surfaktan anionik seperti LAS (Linear alkyl Benzene sulphonate). pada percobaan ini LAS dapat menyerap sinar pada daerah uv dengan panjang gelombang maksimumnya adalah $223,5 \mathrm{~nm}$. LAS dalam perairan dapat menimbulkan potensi masalah pencemaran.Tujuan dari penelitian ini adalah sebagai salah satu alternatif penanganan masalah pencemaran limbah domestik dengan cara menguji kinerja bentonit alam dan bentonit termodifikasi kitosan dalam mengadsorpsi LAS. Untuk mengetahui bahwa kitosan telah bereaksi dengan bentonit maka diuji dengan FTIR dan XRD pada bentonit alam dan bentonit-kitosan. Kemudian ditentukan waktu kontak optimum antara LAS dengan bentonit alam dan bentonit-kitosan. Serta penentuan isoterm adsorpsi LAS dengan bentonit alam dan bentonit-kitosan dengan cara membuat variasi konsentrasi larutan LAS. Uji kinerja bentonit alam dan bentonit-kitosan dalam mengadsorpsi LAS dilakukan dengan menggunakan sistem batch. Didapat waktu kontak optimum antara LAS berinteraksi dengan bentonit alam adalah 15 menit dengan kapasitas adsorpsi sebesar 3,265 mg/g. Sedangkan Waktu kontak optimum interaksi LAS dengan bentonit-kitosan terjadi pada waktu 15 menit dengan kapasitas adsorpsi sebesar 1,7mg/g. Dari hasil yang didapat maka dapat terlihat bahwa bentonit alam memiliki kapasitas adsorpsi yang lebih besar dibandingkan bentonit hasil modifikasi dengan kitosan. Interaksi antara bentonit alam dan bentonit-kitosan dengan LAS terjadi secara fisik dengan energi adsorpsi bentonit alam dengan LAS adalah 19,31 KJ/mol dan energi adsorpsi bentonitkitosan dengan LAS adalah 19,60 KJ/mol.
\end{abstract}

Kata kunci : adsorpsi, LAS, bentonit, kitosan.

\section{THE STUDY OF ADSORPTION LINEAR ALKYL BENZENE SULPHONATE (LAS) USING BENTONITE-CHITOSAN}

\begin{abstract}
Detergents are generally composed of anionic surfactants such as LAS (Linear Alkyl Benzene sulphonate). In this experiment the LAS can absorb light in the UV region at the maximum wavelength at $223.5 \mathrm{~nm}$. LAS in the water can lead to potential pollution problems. The purpose of this study is as an alternative treatment of domestic sewage pollution problem by examining the performance of natural bentonite and bentonite modified chitosan in adsorb LAS. To know the chitosan has reacted with bentonite, the natural bentonite and bentonite-chitosan were investigated using FTIR and XRD. Then, the optimum contact time between the LAS with natural bentonite and bentonite-chitosan were investigated. LAS adsorption isotherms and determination of the natural bentonite and bentonite-chitosan by varying the concentration of LAS solution. Test performance of natural bentonite and bentonite-chitosan adsorbed of LAS was performed using a batch system. Obtained optimum contact time between the LAS (Linear Alkyl Benzene
\end{abstract}


sulphonate) interact with natural bentonite is 15 minutes with the adsorption capacity of $3.265 \mathrm{mg} / \mathrm{g}$. While the optimum contact time interaction with a bentonite-chitosan and LAS occurred at 15 minutes with the adsorption capacity of $1.7 \mathrm{mg} / \mathrm{g}$. From the results, it can be seen that the natural bentonite has a greater adsorption capacity than bentonite modified with chitosan physic. Interaction between natural bentonite and bentonitechitosan with LAS was occured with natural bentonite adsorption energy with the LAS was $19.31 \mathrm{KJ} / \mathrm{mol}$ and the adsorption energy of bentonite - chitosan with the LAS was $19.60 \mathrm{KJ} / \mathrm{mol}$.

Key words : adsorption, LAS, bentonite, chitosan.

\section{PENDAHULUAN}

Air sanggat berharga bagi kehidupan manusia, hewan dan tanaman. Tetapi kualitas air semakin lama semakin menurun saat ini. Salah satu penyebab menurunnya kualitas air adalah akibat pencemaran yang menyebabkan menurunnya kualitas air. Penyebab pencemaran dapat berasal dari aktivitas manusia dan salah satu sumber pencemaran tersebut berasal dari limbah rumah tangga. Pencemaran akibat limbah yang berasal dari rumah tangga disebut dengan pencemaran domestik dan limbahnya disebut dengan limbah domestik.

Limbah cair domestik yang paling tinggi volumenya adalah limbah deterjen. Adanya limbah deterjen perlu diwaspadai karena kandungan bahan aktif yang ada di dalamnya menganggu kesehatan (Rochman, 2009). Salah satu bahan aktif penyusun deterjen adalah Surfaktan (surface active agent). Deterjen pada umumnya tersusun atas surfaktan anionik seperti LAS (Linear alkyl Benzene sulphonate). LAS dalam perairan berpotensi dapat menimbulkan masalah pencemaran. Salah satu cara menangani masalah pencemaran limbah domestik tersebut yaitu dengan mempelajari kinerja bentonit dalam mengadsorpsi LAS. Menurut Al-Sa'adi dan AlMe'ammar (2008) bahwa bentonit yang berasal dari negara Iraq memiliki kemampuan untuk menyerap LAS.
Sehingga dilakukan suatu kajian untuk mengetahui kemampuan bentonit yang berasal dari Indonesia yang telah dimodifikasi dengan kitosan dalam mengadsorpsi LAS.

Bentonit adalah sejenis lempung yang banyak mengandung mineral montmorillonit. mineral pada bentonit memiliki struktur lapis dengan tipe 2:1. Montmorillonit memiliki struktur berlapis-lapis. Bahan berlapis umumnya mampu menginterkalasi senyawasenyawa organik, ion ataupun senyawasenyawa anorganik. Mineral bentonit memiliki lapisan-lapisan silikat bermuatan negatif dengan kation-kation di dalam antarlapisnya dan memiliki kemampuan mengembang yang baik. Sifat mengembang dari montmorillonit menjadi suatu alasan mengapa bentonit dapat menyerap suatu senyawa, baik organik maupun anorganik (Robert, 2012). Sifat daya serap yang dimiliki bentonit terjadi karena adanya ruang poripori antar ikatan mineral lempung. Semakin tinggi luas permukaan bentonit maka semakin besar daya serapanya.

Organobentonit (organoclay) merupakan hasil pemodifikasian mineral bentonit dengan menggunakan kationkation organik. Sintesis organobentonit telah banyak dilakukan. Seperti dengan asam amino histidin, histidin-bentonit memiliki kelemahan karena asam amino tidak setabil pada perubahan suhu dan rentang terhadap bakteri (Nurlamba dan Nessha, 2010). Bentonit yang 
dimodifikasi dengan surfaktan telah banyak diteliti dan diaplikasikandalam pengolahan limbah, tetapi penggunaan surfaktan dikhawatirkan dapat menimbulkan masalah baru terhadap lingkungan, karena surfaktan dapat menghasilkan polutan dari residu yang dihasilkan. Oleh karena itu digunakan kitosan sebagai pemodifikasian bentonit yang lebih aman untuk digunakan (Della, dkk., 2011). Tujuan dari penelitian ini adalah sebagai salah satu alternatif penanganan masalah pencemaran limbah domestik dengan cara menguji kinerja bentonit alam dan bentonit termodifikasi kitosan dalam mengadsorpsi LAS.

\section{METODE PENELITIAN}

\section{A. Alat dan Bahan}

Peralatan yang digunakan adalah penyaring vakum, hot-plate, pengaduk magnet, oven, kertas $\mathrm{pH}, \mathrm{pH}$ meter, kertas saring whatman no 42, ayakan 106 mikron, sepektrofotometer UVVis,spektrofotometer Fourier Transform Infrared (FTIR), X-Ray Diffraction (XRD) Shimadzu 6000 dan alat-alat gelas kimia standar.

Bahan-bahan yang digunakan dalam penelitian ini adalah bentonit, kitosan, asam asetat 98\%, larutan standar surfaktan LAS $96 \%$ (Linear alkyl Benzene sulphonate) dan aquades.

\section{B. Sintesis Bentonit-Kitosan}

Sebanyak 0,1 gram kitosan dilarutkan dalam $100 \mathrm{~mL}$ asam asetat $2 \%$ kemudian dicampurkan dengan bentonit sebanyak 18 gram. Campuran diaduk selama 1,5 jam, kemudian disaring dengan penyaring vakum dan dicuci dengan aquades sampai bebas asam. Kemudian dikeringkan dengan menggunakan oven pada suhu $50{ }^{\circ} \mathrm{C}$ lalu digerus dan diayak dengan ayakan 150 mesh.
Bentonit alam dan bentonit-
kitosan yang didapat kemudian dikarakterisasi dengan menggunakan spektrofotometer Fourier Transform Infrared dengan range bilangan gelombang 300-4000 $\mathrm{cm}^{-1}$ dan dengan metode difraksi sinar X (XRD).

\section{Pengukuran Panjang Gelombang Maksimum LAS}

Lima puluh $\mathrm{mL}$ larutan LAS dengan konsentrasi 20 ppm ditentukan panjang gelombang maksimum menggunakan spektrofotometer UV-Vis. Penentuan panjang gelombang maksimum dilakukan pada rentang panjang gelombang 210-250 $\mathrm{nm}$.

\section{Penentuan Waktu Optimum Adsorpsi LAS dengan Bentonit Alam dan Bentonit-Kitosan}

Larutan LAS dengan konsentrasi 20 ppm ditambah dengan 0,1 gram bentonit-kitosan. Kemudian diaduk selama 3, 7, 10, 15, 20 dan 25 menit. Disaring menggunakan kertas saring whatman no 42. Hasil penyaringan kemudian diukur absorbansinya menggunakan spektrofotometer UV-Vis pada panjang gelombang maksimum. Hasil absorbansi dihitung konsentrasinya dan ditentukan waktu optimumnya

\section{E. Interaksi Kitosan dengan LAS}

Kitosan ditimbang sebanyak 0,1 gram, kemudian direaksikan dengan 50 $\mathrm{mL}$ LAS dengan konsetrasi $15 \mathrm{ppm}$, pengadukan dilakukan selama 15 menit. Hasil kemudian diukur absorbansinya menggunakan spektrofotometer UV-Vis pada panjang gelombang maksimum. 


\section{F. Penentuan Isoterm Adsorpsi LAS dengan Bentonit Alam dan Bentonit-Kitosan}

Larutan LAS standar dibuat pada konsentrasi $6 ; 10 ; 15 ; 18$ dan 20 ppm pada labu takar $50 \mathrm{~mL}$. Kemudian ditambah dengan 0,1 gram bentonit alam, kemudian diaduk selama 15 menit pada suhu ruang $\left( \pm 29 \quad{ }^{\circ} \mathrm{C}\right)$ dan disaring menggunakan kertas saring whatman no 42. Hasil penyaringan kemudian diukur absorbansinya pada panjang gelombang maksimum. Hasil absorbansi dihitung konsentrasinya dan ditentukan isoterm reaksinya. Untuk data penunjang dilakukan karakterisasi bentonit alam yang telah dikontakkan dengan LAS menggunakan FTIR. Untuk bentonitkitosan dilakukan cara yang sama dengan mengganti bentonit alam dengan bentonit kitosan.

\section{HASIL DAN PEMBAHASAN}

\section{A. Sintesis Bentonit-Kitosan}

Kitosan yang digunakan pada proses ini sebanyak 0,1 gram yang dilarutkan dalam $100 \mathrm{~mL}$ asam asetat $2 \%$. Kemudian ditambah dengan 18 gram bentonit dan diaduk selama 1,5 jam. Proses ini dilakukan pada $\mathrm{pH}$ 3. Kitosan mudah larut pada $\mathrm{pH}$ rendah sehingga membuat kitosan akan lebih mudah berinteraksi dengan bentonit. Kitosan merupakan polimer yang dapat bermuatan positif karena memiliki gugus amina. Pada $\mathrm{pH}$ rendah kitosan berada dalam spesi kationiknya sehingga akan lebih mudah untuk berinteraksi dengan permukaan bentonit (Nurlamba dan Nessha, 2010) (Anna, dkk., 2010).

\section{B. Karakterisasi Menggunakan FTIR}

Karaktersasi menggunakan instrumen FTIR dilakukan untuk mengidentifikasi gugus fungsi yang ada pada bentonit alam dan bentonit-kitosan. Hasil spektra antara bentonit alam dan bentonit-kitosan tidak memiliki perbedaan yang signifikan. Bentonit alam yang belum dilakukan pemurnian masih memiliki pengotor senyawa organik. Hal ini terlihat pada spektra FTIR bentonit alam terdapat vibrasi ulur $\mathrm{C}-\mathrm{C}$ sakarida pada panjang gelombang $910,4 \mathrm{~cm}^{-1}$ yang merupakan gugus yang sering muncul pada senyawa organik, sehingga meski direaksikan dengan kitosan yang merupakan senyawa organik maka spektra FTIR bentonit alam tidak memberikan perubahan yang signifikan.

Pada Gambar 1 didapat spektra FTIR untuk bentonit alam dan bentonitkitosan terdapat puncak yang hampir sama. Puncak tersebut terlihat pada bilangan gelombang $470,63 \mathrm{~cm}^{-1}$ yang merupakan vibrasi tekuk Si-O, bilangan gelombang 1033,85 $\mathrm{cm}^{-1}$ menunjukkan vibrasi ulur C-O-C, bilangan gelombang $1635,64 \mathrm{~cm}^{-1}$ yang merupakan vibrasi tekuk $\mathrm{H}-\mathrm{O}-\mathrm{H}$ dan bilangan gelombang $3626,17 \mathrm{~cm}^{-1}$ yang merupakan vibrasi ulur O-H pada (Mg-Al)-OH (Anna, dkk., 2010).

Vibrasi ulur $\mathrm{H}-\mathrm{O}-\mathrm{H}$ pada bentonit alam adalah 3448,72 $\mathrm{cm}^{-1}$. Sedangkan pada bentonit-kitosan vibrasi ulur $\mathrm{H}-\mathrm{O}-\mathrm{H}$ mengalami pergeseran menjadi 3417,86 $\mathrm{cm}^{-1}$. Serta vibrasi tekuk $\mathrm{Si}-\mathrm{O}-\mathrm{Al}$ atau Si$\mathrm{O}-\mathrm{Mg}$ pada bentonit alam adalah 532,35 $\mathrm{cm}^{-1}$, sedangkan bentonit-kitosan mengalami pergeseran menjadi $524,6 \mathrm{~cm}^{-}$ 1. Hal ini menunjukkan bahwa terjadi pergeseran pada gugus fungsi vibrasi ulur $\mathrm{H}-\mathrm{O}-\mathrm{H}$ dan vibrasi tekuk $\mathrm{Si}-\mathrm{O}-\mathrm{Al}$ atau $\mathrm{Si}-$ $\mathrm{O}-\mathrm{Mg}$ pada bentonit alam bila dibandingkan dengan bentonit-kitosan, penurunan energi vibrasi ini mengindikasikan adanya interaksi yang terjadi antara bentonit dengan kitosan (Anna, dkk., 2010). 


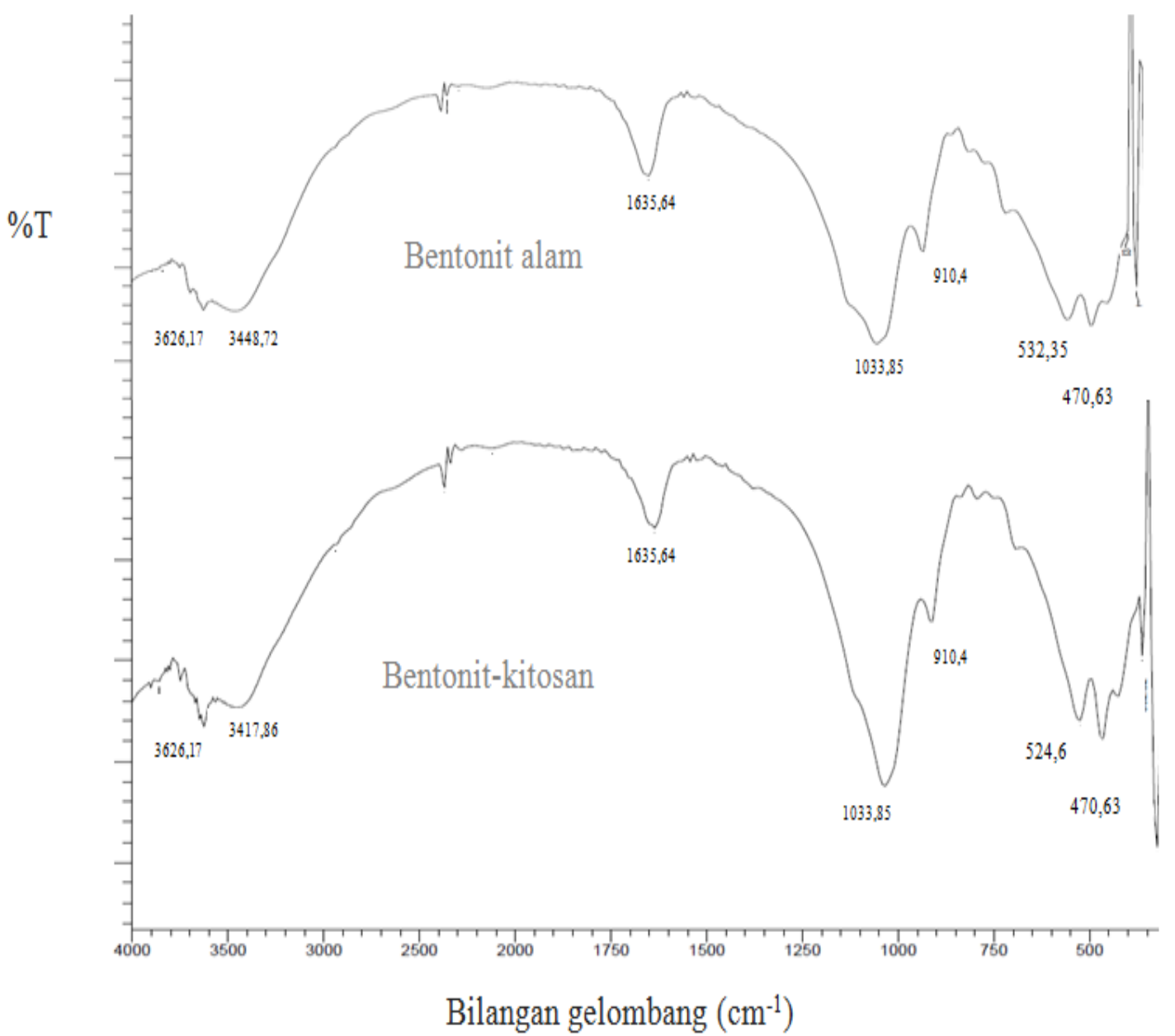

Gambar 1. Spektra FTIR Bentonit Alam dan Bentonit-Kitosan

\section{Karakterisasi menggunakan XRD}

Analisis dengan instrumen XRD dilakukan untuk mengetahui struktur kristal dari bentonit alam dan bentonitkitosan. Difraksi sinar X (XRD) digunakan untuk menganalisis perubahan struktur dari bentonit alam yang dibandingkan dengan struktur bentonitkitosan, terutama untuk lebih memastikan bahwa kitosan telah berinteraksi dengan bentonit. Dari Gambar 2 terlihat spektra XRD bentonit memiliki pita serapan mineral bentonit yang khas, yaitu untuk bentonit alam terlihat pita serapan yang khas pada $2 \Theta$ sebesar 6,$1 ; 20,2437$; dan 26,93 dan jarak bidangnya berturut-turut adalah 14,47731 $\AA$, 4,3831 $\AA$, dan 3,31 $\AA$. Hal ini sesuai dengan ruang $\mathrm{d}_{001}, \mathrm{~d}_{100}$ dan $\mathrm{d}_{103}$ yang khas pada mineral montmorillonit. Spektra XRD dari bentonit-kitosan juga memiliki pita serapan senyawa montmorilonit yang khas, yaitu pada $2 \Theta$ sebesar 5,$78 ; 20,18$; dan 26,81dan jarak bidangnya berturutturut adalah 15,27 $\AA$, 4,39 $\AA$, dan 3,32

Spektra XRD untuk bentonit-kitosan memberikan hasil pergeseran cukup besar dengan bentonit alam terjadi pada ruang $\mathrm{d}_{001}$.Pergeseran jarak antar bidang pada bentonit alam yang berbeda dengan jarak antar bidang pada bentonit-kitosan dikarenakan kitosan telah bereaksi dengan bentonit sehingga terjadi perubahan pada luas jarak bidang dari mineral bentonit alam sebesar 14,47731 $\AA$, dengan mineral bentonit-kitosan yang mengalami perubahan menjadi 15,27808 A. Perubahan luas jarak bidang menjadi lebih besar pada mineral bentonit yang dimodifikasi oleh kitosan menunjukkan bahwa terjadi kontak pada lapisan 
Kajian adsorpsi linear alkyl benzene sulphonate... (Miftah Rifai dan Irwan Nugraha)

mineral bentonit sehingga terjadi perluasan jarak bidang $\mathrm{d}_{001}$ pada bentonitkitosan.

Masuknya kation organik seperti kitosan diantara lapis pada mineral bentonit menggantikan kation penyeimbang muatan lapis silikat pada mineral bentonit menyebabkan ekspansi jarak antara lapis silikat montmorillonit. Ekspansi ini terukur oleh difraksi sinar X (XRD) melalui pergeseran puncak difraksi bentonit alam dengan bentonitkitosan. Pola ekspansi jarak antara lapis $\mathrm{d}_{001}$ pada bentonit-kitosan yang disintesis dari bentonit alam menunjukkan jarak antar lapis silikat montmorilonit. Jarak bidang bentonit alam sebesar 14,47731 $\AA$, berubah menjadi $15,27808 \AA$ pada bentonit hasil modifikasi dengan kitosan (Arif, 2008).

\section{Pengukuran Panjang Gelombang Maksimum LAS}

Pengukuran pada panjang gelombang maksimum akan meningkatkan kepekaan analisis sehingga dapat mengurangi galat dalam menentukan konsentrasi LAS. Serapan maksimum LAS terjadi pada panjang gelombang 223,5 nm. Hal ini membuktikan bahwa LAS dapat menyerap cahaya pada daerah uv yaitu pada panjang gelombang maksimum 223,5 nm. Puncak pada panjang gelombang 223,5 nm menunjukkan terjadi transisi elektronik dari $\mathrm{n} \rightarrow \pi^{*}$ pada LAS.

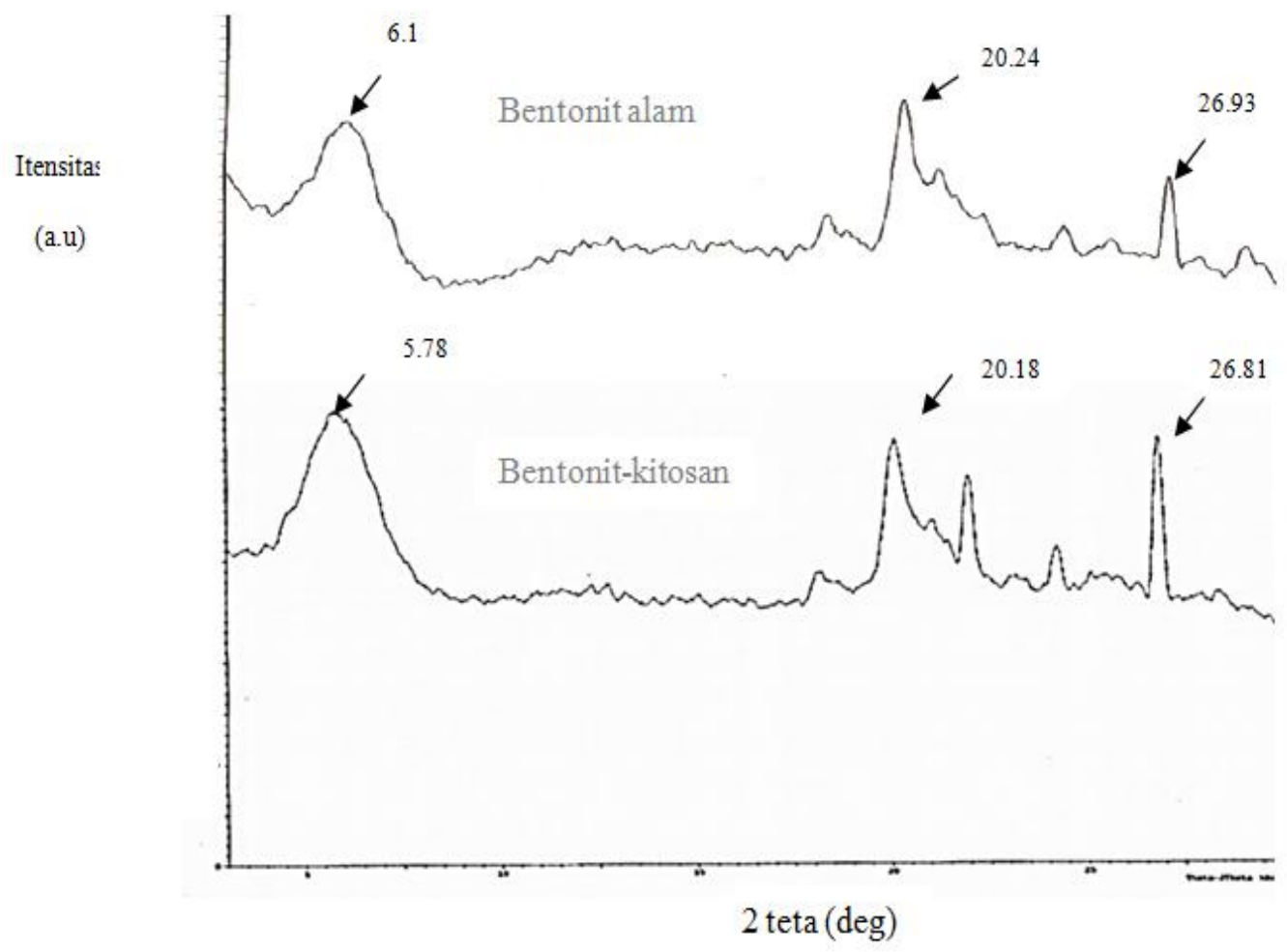

Gambar 2. Difraktogram X-Ray Diffraction (XRD) Bentonit Alam dan Bentonitkitosan 


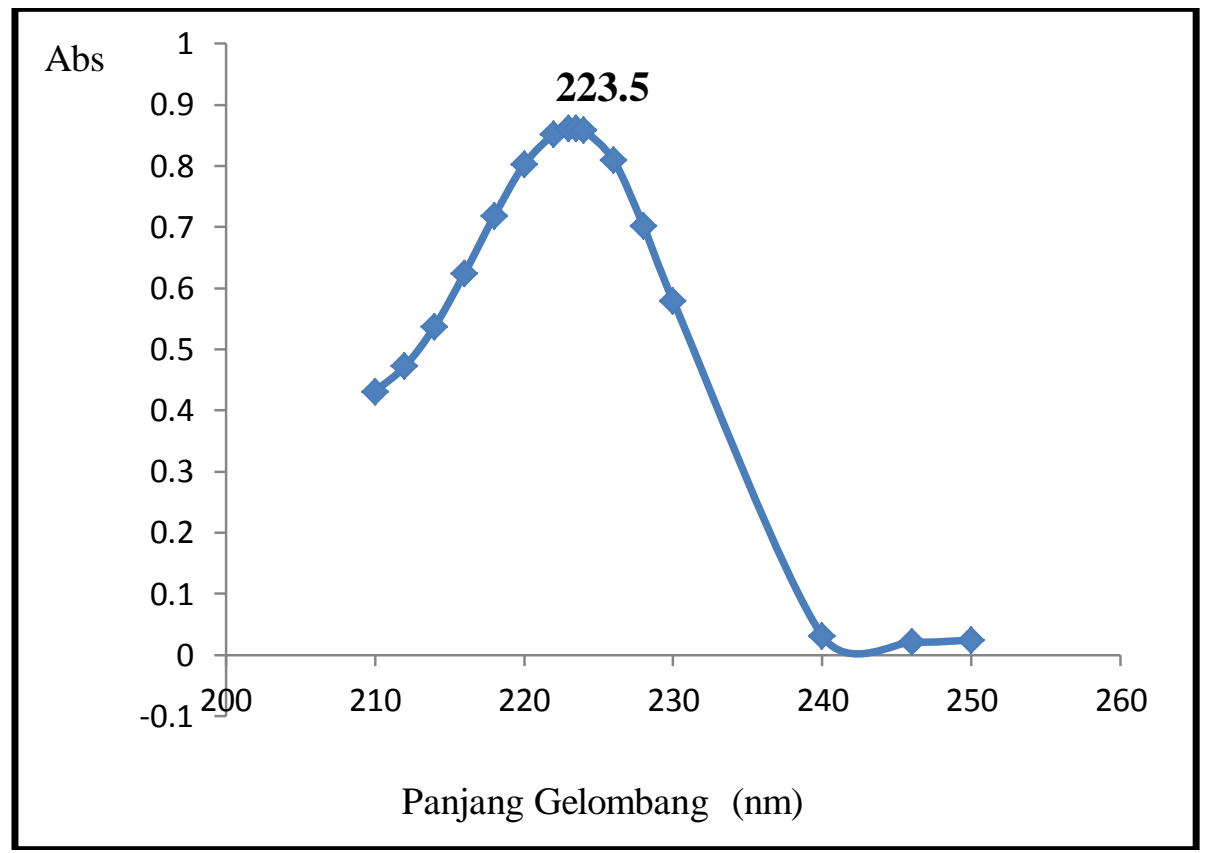

Gambar 3. Kurva Adsorpsi pada Penentuan Panjang Gelombang Maksimum LAS

\section{E. Penentuan Waktu Optimum Adsorpsi}

Penentuan waktu optimum kontak antara LAS dengan bentonit alam dilakukan pada $\mathrm{pH} 4$ dengan konsentrasi LAS adalah $20 \mathrm{ppm}$. Terlihat pada Gambar 4 bahwa waktu optimum kontak larutan LAS dengan bentonit alam maupun bentonit-kitosan terjadi pada waktu 15 menit. Terlihat nilai $Q$ yang meningkat pada selang waktu 3 menit hingga 15 menit. Hal ini terjadi karena situs aktif pada masing-masing adsorben yang masih tersedia atau kondisinya belum jenuh sehingga mengalami kenaikan interaksi dengan LAS yang mengakibatkan kapasitas adsorpsi naik hingga waktu optimumnya tercapai, kemudian mengalami kejenuhan dan terjadi penurunan nilai kapasitas adsorpsi yang menandakan terjadi desorpsi setelah melewati waktu optimum interaksi.

Dari Gambar 4 terlihat bahwa bentonit alam memiliki kapasitas adsorpsi yang lebih besar yaitu 3,265 $\mathrm{mg} / \mathrm{g}$ pada waktu 15 menit, bila dibandingkan dengan kapasitas adsorpsi bentonit hasil modifikasi dengan kitosan yang hanya $1,7 \mathrm{mg} / \mathrm{g}$ pada waktu 15 menit. Ini membuktikan bahwa bentonit yang telah dimodifikasi dengan kitosan memiliki kapasitas adsorpsi yang kurang baik bila dibandingkan dengan bentonit alam. Hal ini dikarenakan kemampuan kitosan yang kurang dapat mengikat LAS bila dibandingkan dengan bentonit alam yang digunakan dalam percobaan ini, terlihat pada Tabel 1 bahwa kitosan memiliki kapasitas adsorpsi sebesar 1,62 $\mathrm{mg} / \mathrm{g}$ terhadap LAS.

Dari Gambar 4 dapat diperoleh hasil bahwa kitosan memiliki kapasitas adsorpsi yang lebih kecil dari pada bentonit alam, sehingga kitosan dimungkinkan menutupi sisi aktif pada bentonit dan saat direaksikan dengan LAS kinerja bentonit-kitosan kurang baik, selain itu perbandingan kitosan dengan bentonit saat sintesis kurang sesuai sehingga kitosan maupun bentonit saling menutupi sisi aktif masing-masing yang membuat kinerja keduanya saat berinteraksi dengan LAS berkurang dan membuat interaksi antara bentonitkitosan dengan LAS kurang maksimal. Hasil disajikan pada Tabel 1. 
Kajian adsorpsi linear alkyl benzene sulphonate... (Miftah Rifai dan Irwan Nugraha)

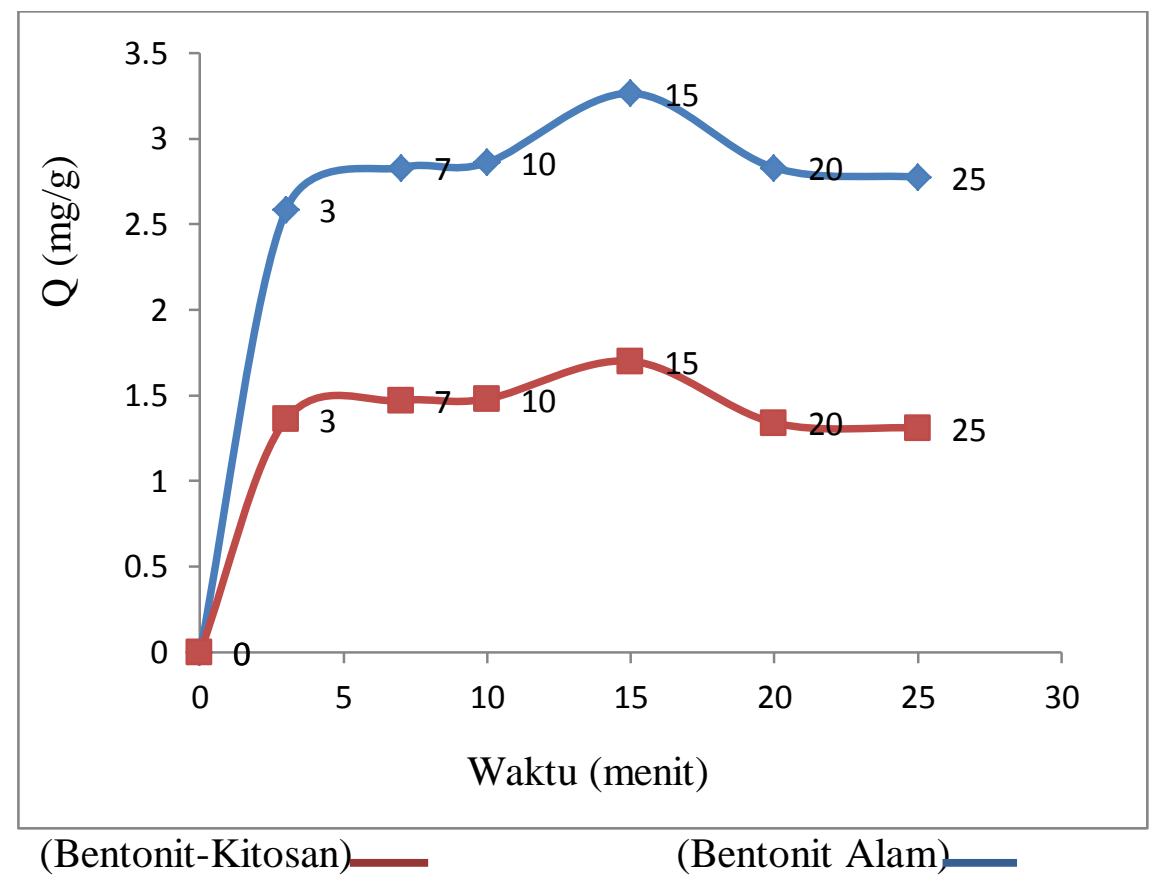

Gambar 4. Hubungan antara Waktu Kontak dengan Kapasitas Adsorpsi antara BentonitKitosan dan Bentonit Alam dengan LAS

Tabel 1. $(Q)$ kapasitas adsorpsi (mg/g) kitosan, bentonit alam dan bentonit-kitosan terhadap LAS 15 ppm dengan waktu pengadukan 15 menit

\begin{tabular}{|l|c|}
\hline Bahan yang di uji & $\begin{array}{c}(Q) \text { kapasitas adsorpsi } \\
(\mathrm{mg} / \mathrm{g})\end{array}$ \\
\hline Bentonit alam & 1,99 \\
\hline Kitosan & 1,62 \\
\hline Bentonit-kitosan & 1,12 \\
\hline
\end{tabular}

\section{F. Penentuan Isoterm Adsorpsi Bentonit Alam dengan Menggunakan LAS}

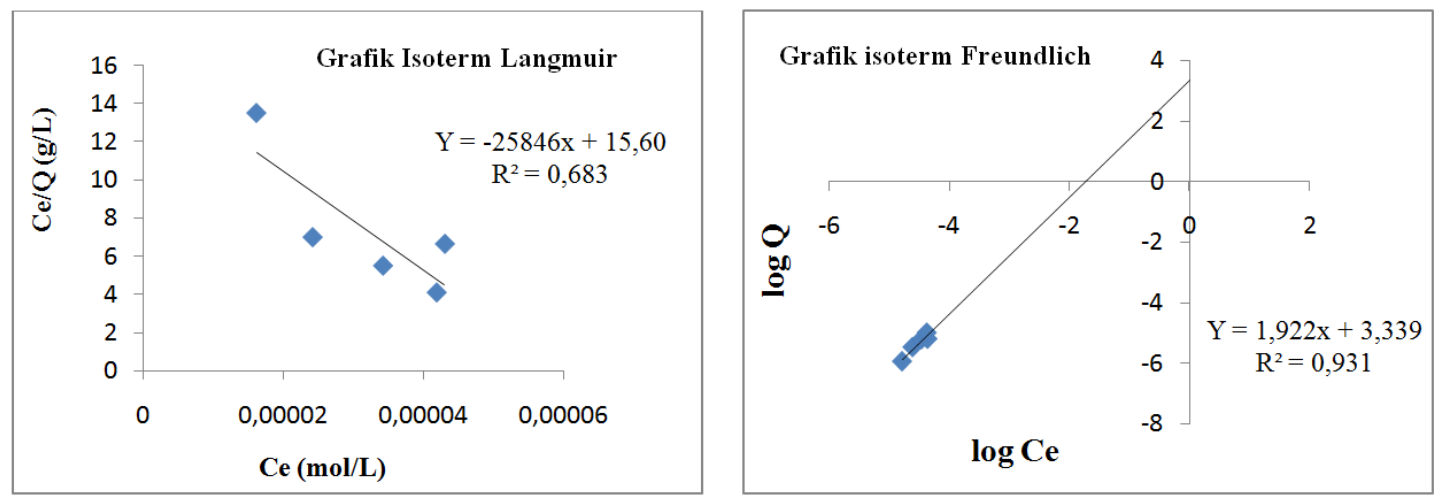

Gambar 5. Grafik Isoterm Adsorpsi Bentonit Alam Dengan LAS 

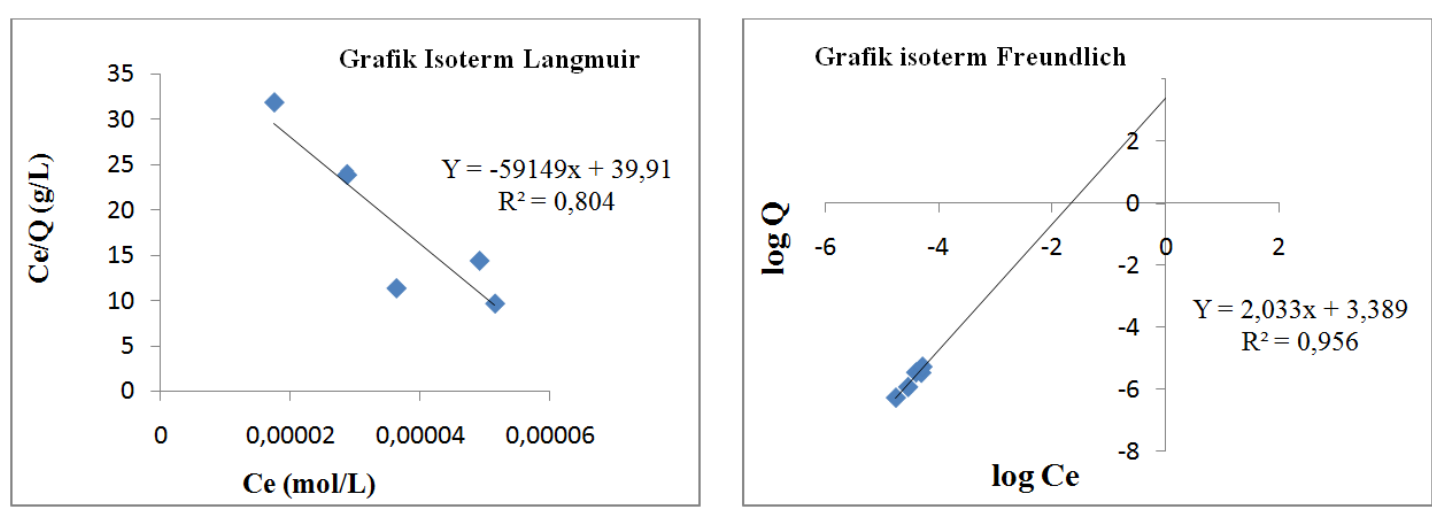

Gambar 6. Grafik Isoterm Adsorpsi Bentonit-Kitosan dengan LAS

Tabel 2. Hasil Perhitungan Isoterm Adsorpsi Langmuir dan Freundlich

\begin{tabular}{|c|c|c|l|}
\hline Nama Adsorben & Model Isoterm & $\mathrm{R}^{2}$ & \multicolumn{1}{|c|}{ Kostanta } \\
\hline \multirow{2}{*}{ Bentonit alam } & Langmuir & $\mathrm{O}, 683$ & $\mathrm{~K}=-1,659 \times 10^{3} \mathrm{~L} / \mathrm{mol}$ \\
\cline { 2 - 4 } & Freundlich & 0,931 & $\mathrm{Kf}=2,1827 \times 10^{3} \mathrm{~L} / \mathrm{mol}$ \\
\hline \multirow{2}{*}{ Bentonit-kitosan } & Langmuir & $\mathrm{O}, 804$ & $\mathrm{~K}=-1,482 \times 10^{3} \mathrm{~L} / \mathrm{mol}$ \\
\cline { 2 - 4 } & Freundlich & 0,956 & $\mathrm{Kf}=2,4491 \times 10^{3} \mathrm{~L} / \mathrm{mol}$ \\
\hline
\end{tabular}

Penentuan isoterm adsorpsi bentonit alam dan bentonit-kitosan dengan LAS dilakukan menggunakan dua model persamaan isoterm adsorpsi, yaitu model isoterm Langmuir dan model isoterm Freundlich. Dari Gambar 5 dan 6 maka didapat hasil perhitungan isoterm Langmuir dan Freundlich pada adsorpsi LAS dengan bentonit alam maupun bentonit-kitosan yang disajikan pada Tabel 2.

Dari Tabel 2 terlihat bahwa adsorpsi LAS menggunakan bentonit alam maupun bentonit-kitosan cenderung mengikuti model isoterm Freundlich karena memiliki nilai linearitas $\left(\mathrm{R}^{2}\right)$ yang lebih besar. Untuk bentonit alam harga linearitas $\left(\mathrm{R}^{2}\right)$ model isoterm Freundlich adalah 0,931. Sedangkan model isoterm Freundlich pada bentonit-kitosan memiliki linearitas $\left(\mathrm{R}^{2}\right)$ sebesar 0,956 . Hal ini diperkuat dengan nilai kostanta keseimbangan (K) pada isoterm Langmuir pada kedua adsorben tersebut bernilai negatif. Nilai negatif pada kostanta keseimbangan isoterm Langmuir menunjukkan bahwa interaksi yang terjadi antara adsorbat dengan adsorben tidak terdefinisikan, sehingga dapat disimpulkan proses adsorpsi pada bentonit alam dan bentonit-kitosan dengan LAS lebih cendrung mengikuti model isoterm Freundlich.

Isoterm Freundlich mengasumsikan bahwa interaksi LAS terjadi pada permukaan heterogen yang bersifat multilayer pada bentonit alam maupun bentonit-kitosan dengan ikatan lemah yang hanya melibatkan interaksi Van der Waals. Hal ini menunjukkan bahwa interaksi antara bentonit alam dengan LAS terjadi secara fisik. Hal ini diperkuat dari Gambar 7 yang terlihat bahwa tidak muncul gugus fungsi baru serta pergeseran spektra yang signifikan antara bentonit alam dengan bentonit alam yang telah berinteraksi dengan LAS, maupun bentonit-kitosan dengan bentonit-kitosan setelah bereaksi dengan LAS. Hal ini menunjukkan bahwa LAS berinteraksi dengan kedua adsorben tersebut tanpa membentuk ikatan secara kimia. 


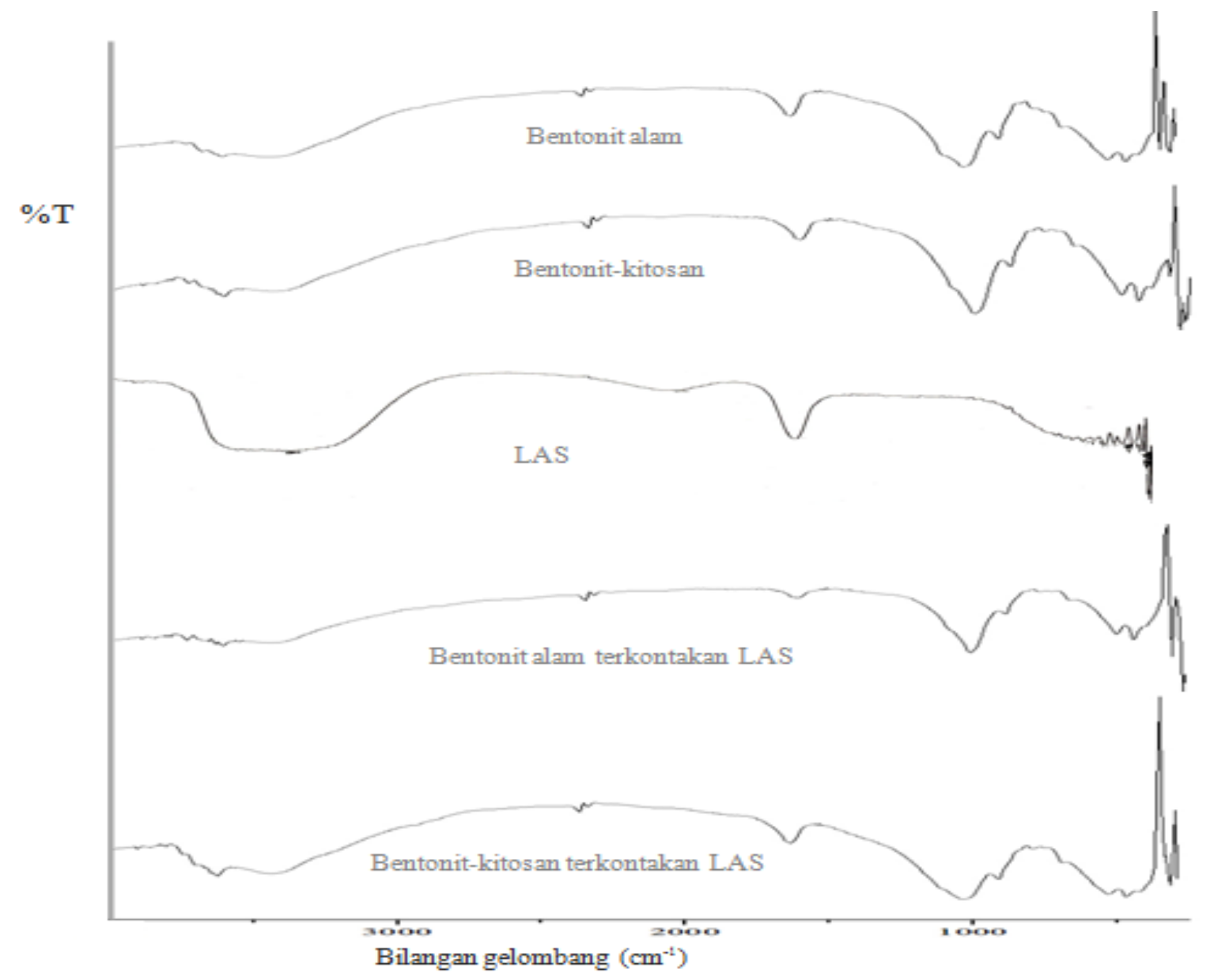

Gambar 7. Spektra FTIR Bentonit alam, Bentonit-Kitosan, LAS, Bentonit-Kitosan terkontakkan LAS dan Bentonit alam terkontakkan LAS

Energi adsorpsi yang terjadi antara LAS dengan bentonit alam adalah sebesar 19,31 KJ/mol (Adamson, 1990). Sedangkan energi adsorpsi antara LAS dengan bentonit-kitosan adalah sebesar 19,60 KJ/mol. Kedua adsorben tersebut berinteraksi dengan LAS secara fisik bila ditinjau dari energi saat berinteraksi dengan LAS. Terlihat bahwa energi adsorpsi dari bentonit-kitosan lebih besar dari nilai energi adsorpsi bentonit alam saat berinteraksi dengan LAS. Energi adsorpsi untuk bentonit-kitosan adalah $19,60 \mathrm{KJ} / \mathrm{mol}$, sedangkan bentonit alam hanya $19,31 \mathrm{KJ} / \mathrm{mol}$.

\section{KESIMPULAN}

Bentonit alam dan bentonitkitosan dapat mengadsorpsi LAS dengan waktu optimum kontak adalah 15 menit. Bentonit alam memiliki kapasitas adsorpsi sebesar $3,265 \mathrm{mg} / \mathrm{g}$, dan lebih besar dari bentonit-kitosan yang hanya $1,7 \mathrm{mg} / \mathrm{g}$ pada waktu kontak 15 menit. Bentonit alam maupun bentonit-kitosan terjadi interaksi secara fisik dengan LAS. Interaksi antara bentonit alam dengan LAS memiliki energi 19,31 $\mathrm{KJ} / \mathrm{mol}$, energi tersebut lebih kecil darienergi interaksi bentonit-kitosan dengan LAS sebesar 19,60KJ/mol. 


\section{DAFTAR PUSTAKA}

Adamson, A.W., 1990, Physical Chemistry of Surfaces, Fifth Edition, John Wiley and Sons, Inc., New York.

Al-Sa'adi dan Al-Me'ammar. 2008. Adsorption Studies Of Linear Alkylbenzene Sulfonate By Using Iraqi Bentonite Clays. Iraqi Journal of Science, Vol.50, No.2, 2009, PP. 144-151.

Anna, Wiwi dan Irnawati. 2010. Uji Kinerja Kitosan-Bentonite Terhadap Logam Berat dan Diazinon Secara Simultan. Jurnal Sains dan Teknologi Kimia Vol 1. No.2 Oktober 2010. Hal 121-134 ISSN 2087-7412.

Arif. 2008. Sintesis Nanokomposit Poliester-Lempung Berbahan Baku Organolempung dari Bentonit Indonesia. Tesis. FIMPA Univesitas Gajah Mada : Yogyakarta.

Della, Anna dan Zackiyah. 2011. Adsorpsi Simultan KitosanBentonit Terhadap Ion Logam Dan Residu Pestisida Dalam Air Minum Dengan Teknik Batch. Program Studi Kimia, Universitas Pendidikan Indonesia. Seminar nasional kimia dan pendidikan kimia UNY, November 2011.
Nurlamba, dan Nessha S, . 2010. Kajian Kinetika Interaksi Kitosan-Bentonit Dan Adsorpsi Diazinon Terhadap Kitosan-Bentonit. Program Studi Kimia, Jurusan Pendidikan Kimia, Universitas Pendidikan Indonesia. Jurnal Sains dan Teknologi Kimia, Vol 1., No.2 Oktober 2010, Hal 159-169 ISSN 2087-7412.

Robert. 2012. Bentonit Pilarisasi Cr dan Zeolit HZSM-5 Sebagai Katalis Pada Proses Konversi Ethanol Menjadi Biogasolin. Tesis. Program Studi Ilmu Material Pascasarjana Fakultas Matematika dan Ilmu Pengetahuan Alam Universitas Indonesia:Salemba.

Rochman, F. 2009. Pembuatan Ipal Mini Untuk Limbah Deterjen Domestik. J. Penelit. Med. Eksakta. Vol. 8, No. 2, Agust 2009: 134-142. 